\title{
Pengaruh Variety Seeking dan Packaging terhadap Brand Switching Studi Konsumen Natasha Skincare di Bandar Lampung
}

\author{
Dwi Apriliani \\ dwiapriliani6894@gmail.com \\ UIN Raden Intan Lampung \\ A. Zuliansyah \\ zuliansyah@gmail.com \\ UIN Raden Intan Lampung \\ Vicky F. Sanjaya \\ vicky@gmail.com \\ UIN Raden Intan Lampung
}

\begin{abstract}
This study uses a quantitative approach. The research was conducted on Natasha skincare consumers in Bandar Lampung. The research sample amounted to 100 respondents using nonprobability sampling technique, namely purposive sampling. Collecting data through the distribution of questionnaires. The data analysis method in this study uses partial least squares structural equation modeling (PLS-SEM) with SmartPLS3 software for data processing. The results show that the hypothesis is supported, namely that there is a positive and significant effect between variety seeking $\left(X_{1}\right)$ on brand switching $(Y)$ on Natasha skincare consumers in Bandar Lampung. This is evidenced by the original sample (O) 0.438 T-statistic value $4.553>1.96$ and P-Values 0.000 $<0.05$, and there is a positive and significant effect between packaging $\left(X_{2}\right)$ on brand switching $(Y)$ with an original sample value $(O)$ of 0.343, a T-Statistic value of $3.197>1.96$ and a P-Values of $0.001<0.05$. Based on $R^{2}$, which is 0.464 or $46.4 \%$, which means that variety seeking and packaging are able to explain the variability of the brand switching construct by $46.4 \%$, and the remaining $54.6 \%$ is influenced by other factors not examined in this study. variety seeking and packaging for brand switching on Natasha skincare consumers in Bandar Lampung.
\end{abstract}

Keywords : brand switching, packaging, variety seeking

\section{Pendahuluan}

Di era globalisasi saat ini perusahaan berlomba-lomba meningkatkan dan mengeluarkan produk terbarunya, persaingan merek industri khususnya kosmetik semakin ketat bersaing. Setiap orang saat ini pasti memiliki kosmetik dimana kosmetik sekarang menjadi produk penting bagi wanita, dalam kesahariannya wanita tidak lepas dari make-up yang mampu memberikan kesan menarik dan memperjelas identitas sosial seorang wanita. Tak jarang bahkan merek kosmetik harus mengikuti keadaan kulit sehingga menyesuaikan kebutuhan masing-masing individu. Bahkan saat ini merek kosmetik yang beredar di pasaran sangat banyak jenisnya, perkembangan yang semakin cepat membuat kosmetik lokal maupun internasional masuk ke Indonesia sehingga konsumen memiliki fikiran untuk melakukan peralihan.

Saat modern ini produk alami mulai digunakan, kosmetik bermunculan dimana-mana dengan berbagai jenis tergantung dari bagian dan kegunaanya salah satunya skincare. Skincare saat ini paling banyak diperbincangkan. Munculnya berbagai trend kecantikan mengenai skincare dapat memberikan pengaruh pada seseorang untuk lebih aware mengenai perawatan kulit dengan baik dan benar, terlebih berbagai macam inovasi dan varian produk saat ini 
bermunculan. Menurut Syauki \& Amalia Avina (2020), adanya merek-merek skincare yang beredar di pasaran, menjadi pertimbangan bagi konsumen untuk memilih produk yang tepat. Karena setiap produk tentunya memiliki keunggulan masing-masing. Oleh karena itu, para konsumen dituntut untuk lebih selektif dalam memilih produk yang beragam mereknya. Apabila konsumen tidak berhati-hati dalam memilih produk terutama produk kecantikan yang seharihari digunakan oleh konsumen, maka dapat membahayakan kesehatan konsumen itu sendiri.

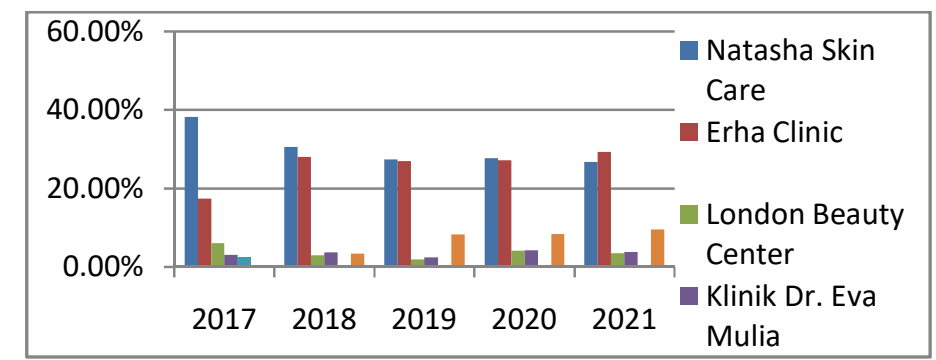

\section{Grafik 1 Top Brand Award Index Skincare di Indonesia 2017-2021}

Dari data grafik Top Brand Award Indexskin care di Indonesia pada tahun 2017 sampai 2020 merek Natasha Skincare selalu ada di top brand award, namun pada tahun 2021 realisasi penjualan Natasha Skincare mengalami penurunan. Hal ini mengalami pertentangan dengan apa yang perusahaan inginkan dengan yang mereka harapkan. Sebenarnya perusahaan menginginkan perusahaanya terus meningkat dan mendapatkan profit yang jelas, tetapi hal ini justru mendapatkan hasil yang menurun di mana terdapat peralihan grafik pada tahun 2021 dari Natasha Skincare ke Erha Clinic.

Peralihan ini bukan tanpa alasan sebab salah satu trend perilaku tersebut yakni adalah keingingan untuk mencoba hal-hal baru, terlebih produsen melihat peluang pangsa pasar yang begitu besar, sehingga para produsen berlomba-lomba menciptakan produk unggulan dengan memberikan inovasi-inovasi terbaru untuk kaum wanita. Asmoningsih (2015) berasumsi bahwa semakin banyaknya persaingan saat ini akan memberikan kesempatan lahirnya berbagai merek baru yang berusaha untuk merebut pasar merek yang telah ada, menambah tantangan untuk tempat perawatan kecantikan dan kesehatan tubuh seperti Erha Clinic, Ristra, Natasha Skincare, dan klinik lain sejenisnya terkhusus pada kota Bandar Lampung.

Klinik kecantikan adalah jasa perawatan kulit yang menawarkan produk dan jasa untuk melindungi, memperbaiki, dan meningkatkan tampilan kulit. Fenomena yang terjadi saat ini di kalangan wanita kecantikan dan penampilan yang menarik menjadi magnet dan menjadi peran penting, kebanyakan wanita yang memandang kecantikan sebagai hal yang utama, mereka melakukan berbagaimacam perawatan untuk menjaga kecantikan dan menjagapenampilannya agar tetap menarik, baik itu perawatan fisik ataupun non fisik. Untuk itukonsumen memilih tempat kecantikan yang mempunyai kualitas baik dari segi produkataupun kebutuhan yang mereka butuhkan. Hal ini membuat kota Bandar Lampung menjadi salah satu kota yang banyak terdapat klinik kecantikan dengan menjual skincare berdasarkan Dinas Kesehatan Kota Bandar Lampung. Penelitian yang di lakukan oleh Lestira, Warganegara, \& Alviyani (2020) dapat menyimpulkan bahwa Natasha Skincare di kota Bandar Lampung merupakan pemimpin pangsa pasar dengan perolehan $22 \%$, maka dengan banyaknya pesaing tempat yang memberikan jasa perawatan kecantikan Natasha Skincare harus mampu memberikan pelayanan serta memberikan produk yang berkualitas sesuai dengan yang diinginkan oleh konsumen, sehingga konsumen akan merasa puas dan akan kembali menggunakan jasa maupun produknya.

Perpindahan merek (brand switching) dapat diartikan sebagai hasil dari ketidakpuasan konsumen akan suatu produk yang mengakibatkan konsumen melakukan penghentian pembelian produk pada suatu merekdan menggantinya dengan produk dari merek lain (Yunita \& Rosa, 2016). Sulistyo \& Maftukhah (2016) berasumsi bahwa alasan utama yang sering dialami oleh konsumen ketika mereka melakukan perpindahan merek adalah pada saat setelah produk dibeli (pasca pembelian), para konsumen dalam melakukan perpindahan merek biasanya 
mengacu pada kualitas produk yang tidak sesuai dengan diharapkan atau yang dijanjikan, akibat dari ketidakpuasan konsumen, maka konsumen bisa saja mencari media (media search) untuk mendapatkan berbagai informasi mengenai produk yang dapat memuaskan kebutuhan dan keinginannya.

Indriyani \& Pasharibu (2020) mengatakan konsumen sering membandingkan berbagai merek dan memilih yang terbaik. Perilaku beralih merek konsumen sangat mempengaruhi kapasitas pendapatan dan daya saing perusahaan, statistik menunjukan bahwa keuntungan telah berkurang $25-50 \%$ karena penghianatan konsumen.Semua itu bisa terjadi dan dialami konsumen dan membuat konsumen mengalami ketidak puasan dan beralih ke merek perusahaan lain (brand switching). Baek and Kim (2018) memberikan analogi bahwa secara umum individu yang memiliki perilaku perpindahan merek akan cenderung mempunyai rasa mengeluh yang tinggi diakibatkan karena barang yang dibeli tidak sesuai. Sehingga asumsi setiap individu berusaha untuk terus beralih ke merek baru semakin terencana. Berdasarkan analogi tersebut dapat dipahami bahwa perilaku perpindahan merek membawa dampak negatif bagi individu.

Namun, pernahkah kita membayangkan bahwa sesorang yang memiliki jiwa peralihan merek yang tinggi mempunyai fokus ketelitian yang sangat baik dalam memahami sesuatu. Ariani (2014) mengatakan bahwa seseorang yang memiliki ketelitian yang tinggi sangat diperlukan sebab dalam perusahaan ketelitian mengenai detail brand yang baik akan membuat konsumen menjadi percaya pada mereknya. sehingga memberikan pengaruh positif terhadap kinerja perusahaan. Oleh sebab itu penelitian ini akan menguji apakah perilaku brand switching yang dilakukan saat ini selalu memiliki dampak negatif? Atau bahkan justru memiliki dampak positif.

Kapojos (2017) mengatakan bahwa salah satu faktor internal yang mempengaruhi perilaku perpindahan merek yaitu salah satunya adalah keinginan mencari variasi (variety seeking). Septiani \& Purwanti (2020) berasumsi kebutuhan mencari variasi (variety seeking) adalah suatu hal yang dimiliki oleh sebagian konsumen. Mengidentifikasi pelanggan yang suka mencari variasi merupakan salah satu hal yang penting bagi perusahaankarena perilaku perpindahan merek (brand switching) dapat munculkarena adanya kebutuhan mencari variasi (variety seeking), namun Wahyuni \& Kurniawati (2018) dalam penelitiannya mengatakan bahwa variety seeking menurun, maka brand switching akan meningkat. Dapat diartikan bahwa

Jannah (2018) pelanggan yang mencari variasiberbeda pada situasi yang bercirikan rendahnya keterlibatan konsumen namun perbedaan merek dianggap cukup berarti. menyatakan bahwa terdapat faktor-faktor yang mempengaruhi brand switching, yaitu:

1) Atribut Produk

Tjiptono \& Fandy (2015) memberikan definisi atau pengertian atribut produk sebagai unsur-unsur produk yang dipandang penting oleh konsumen dan dijadikan dasar pengambilan keputusan pembelian. Atribut produk meliputi: mutu, merek, kemasan, jaminan dan sebagainya.

2) Mutu produk adalah kemampuan produk untuk melaksanakan fungsinya, termasuk keawetan, kehandalan, ketepatan, kemudahan dipergunakan dan diperbaiki, serta atribut bernilai yang lain.

3) Merek merupakan nama, istilah, tanda, simbol/lambang, desain, warna, gerak, atau kombinasi atribut-atribut produk lainnya yang diharapkan dapat memberikan identitas dan diferensiasi terhadap produk pesaing.

4) Pengemasan (packaging) merupakan proses yang berkaitan dengan perancangan dan pembuatan wadah (container) atau pembungkus (wrapper) untuk suatu produk. Pemberian kemasan pada suatu produk bisa memberikan tiga manfaat utama, yaitu manfaat komunikasi, manfaat fungsional, dan manfaat perceptual.

5) Jaminan yaitu janji yang merupakan kewajiban produsen atas produknya kepada konsumen, dimana para konsumen akan diberi ganti rugi bila produk ternyata tidak bisa berfungsi sebagaimana yang diharapkan atau dijanjikan. Jaminan bisa meliputi kualitas produk, reparasi, ganti rugi (uang kembali atau produk ditukar), dan sebagainya. 
Variabel penjelas ini merupakan faktor yang melatarbelakangi keputusan perpindahan merek produk skincare. Salah satu faktor tersebut adalah packaging, Pertiwi (2020) berasumsi bahwa teknologi telah membuat packaging berubah fungsi. Jika dulu "Packaging protects what it sells (Kemasan melindungi apa yang dijual)." Sekarang,"Packaging sells what it protects (Kemasan menjual apa yang dilindungi)." Dengan kata lain, kemasan bukan lagi sebagai pelindung atau wadah tetapi harus dapat menjual produk yang dikemasnya. Estiyanti dkk (2019) mendefinisikan proses kemasan melibatkan kegiatan mendesain dan memproduksi. Fungsi utama dari kemasan yaitu untuk melindungi produk agar produk tetap terjaga kualitasya. Desain kemasan yang meliputi desain grafis, struktur desain, dan informasi produk memberikan pengaruh cukup tinggi.

\section{Kajian Teori}

\subsection{Perilaku Konsumen}

Perilaku konsumen didefinisikan oleh para pakar dengan berbeda-beda tergantung pendekatan yang digunakan oleh masing-masing pakar. Berikut ini beberapa pengertian perilaku konsumen menurut para ahli sebagai berikut:

1) Sunyoto (2012) mendefinisikan perilaku konsumen merupakan suatu tindakan-tindakan yang dilakukan oleh individu, kelompok atau organisasi yang berhubungan dengan proses pengambilan keputusan dalam mendapatkan, dan menggunakan barang-barang atau jasa ekonomi yang dapat dipengaruhi oleh lingkungan.

2) Kotler dan Keller (2017) mengartikan perilaku konsumen sebagai studi tentang bagaimana individu, kelompok, dan organisasi memilih, membeli, menggunakan, dan bagaimana barang, jasa, ide, atau pengalaman untuk memuaskan kebutuhan dan keinginan mereka.

3) Peter J. Paul dan Jerry C Olson (2006) menyatakan bahwa perilaku konsumen merupakan interaksi dinamis antara pengaruh dan kondisi perilaku dan kejadian di sekitar lingkungan dimana manusia melakukan aspek pertukaran dalam kehidupan mereka.

Berdasarkan penjelasan di atas dan dari beberapa definisi di atas dapat dilihat ada dua hal penting dari perilaku konsumen yaitu proses pengambilan keputusan dan kegiatan fisik yang semuanya ini melibatkan individu dalam menilai, mendapatkan dan mempergunakan barangbarangdan jasa secara ekonomis. Dengan kata lain perilaku konsumen adalah ilmu yang mempelajari tingkah laku konsumen dalam arti tindakan yang dilakukan untuk membeli suatu barang dan jasa.

1) Pengertian perilaku konsumenTentang Perpindahan Merek

a) Menurut Kotler dan Keller (2017), bidang ilmu perilaku konsumen mempelajari bagaimana individu, kelompok, dan organisasi memilih, membeli, memakai, serta memanfaatkan barang, jasa, gagasan, atau pengalaman dalam rangka memuaskan kebutuhan dan hasrat mereka. Jika produsen melebihlebihkan manfaat suatu produk maka harapan konsumen tidak akan tercapai sehinggga mengakibatkan ketidakpuasan. Selanjutnya Kotler dan Keller (2017) menyatakan bahwa ketidakpuasan adalah suatu keadaan di mana pengharapan konsumen tidak sama atau lebih tinggi daripada kinerja yang diterimanya dari pemasar. Sehingga menyebabkan adanya perilaku memilih produk yang sesuai kebutuhan, jika kebutuhan tidak terpenuhi maka konsumen bisa saja beralih kemerek lain.

b) Menurut Swastha \& Handoko (2012), perilaku konsumen dapat terjadi karena perpindahan merek dengan adanya mencari keragaman (variety seeking). Seperti sudah disebutkan dalam loyalitas merek, bahwa konsumen yang hanya mengaktifkan tahap kognitifnya dapat dihipotesiskan sebagai konsumen yang paling rentan terhadap perpindahan merek karena adanya rangsangan pemasaran. Penyebab lain perpindahan merek dapat berasal dari sangat beragamnya penawaran produk lain, atau kadang-kadang karena terjadi masalah dengan produk yang sudah dibeli. 
2) Macam-Macam Perilaku Konsumen Tentang Perpindahan Merek

a) Perilaku membeli yang kompleks

Misalnya, si X ingin membeli laptop seharga Rp. 40 juta, tentu $X$ sebelum memutuskan pembelian melakukan proses berfikir terlebih dahulu, sebab produk tersebut jarang sekali dibeli, belum lagi harganya relatif mahal. Inilah yang dimaksud dengan perilaku pembelian yang kompleks.

b) Perilaku membeli yang mengurangi disonansi

Saat punya perilaku ini, konsumen akan sangat terlibat dalam proses pembelian. Akan tetapi, mereka kesulitan menentukan perbedaan antar merek.

c) Perilaku membeli yang telah terbiasa

Pemilihan merek didasarkan pada kebiasaan, dengan begitu keputusan pembelian tidak dipengaruhi oleh loyalitas dan kampanye dari produk yang dibeli. Ini tentu berbeda dengan perilaku pembelian yang mengurangi disonansi. Dalam kebiasaan pembelian, konsumen tidak benar-benar terlibat dalam pemilihan merek. Mereka membeli sesuatu hanya karena kebiasaan.

d) Perilaku mencari keragaman produk (variety seeking behavior)

Pada tipe ini, konsumen membeli produk yang berbeda, akan tetapi ini dilakukan bukan karena mereka tidak puas dengan produk sebelumnya, perilaku tersebut didasarkan oleh motivasi untuk mencari variasi dari produk yang mereka miliki.

Perilaku konsumen dapat diartikan sebagai atau kegiatan-kegiatan individu, yang secara langsung terlibat dalam mendapatkan serta menggunakan barang dan jasa termasuk di dalamnya proses pengambilan keputusan pada persiapan dan penentuan. Oleh karena itu, walaupun suatu merek telah melekat dihati konsumen, bila ia tidak bisa berkembang memenuhi selera konsumen, suatu saat merek tersebut akan ditinggalkan oleh konsumennya.

\subsection{Pengembangan Hipotesis}

\subsubsection{Pengaruh Variety Seeking Terhadap Brand Switching}

Pada penelitian Yunita \& Rosa (2016) mengatakan bahwa secara simultan atau berdasarkan hasil uji $\mathrm{F}$ menunjukkan bahwa terdapat pengaruh signifikan antara variabel atribut produk, promosi dan variety seeking terhadap brand switching dan kemudian pada uji determinasi terdapat pengaruh sebesar 63,1 \% yang mempengaruhi brand switching, berarti sikap konsumen yang ingin mencoba produk baru yang baru saja muncul dipasar atau produk lama yang belum dicoba dan memuaskan rasa ingin tahu mereka terhadap merek lain yang membuat perpindahan merek. Hal ini diperkuat dengan penelitian Indriyani \& Pasharibu (2020) yang menyatakan bahwa persaingan yang semakin tinggi menuntut para pelaku bisnis untuk cermat dalam berinovasi mengenai pengembangan mereknya agar bisa bertahan dan tidak tergerus dari merek pesaing. Ini merupakan hal yang terus berlanjut, sehingga mau tidak mau perusahaan harus siap akan resiko tersebut karena jika perusahaan berhasil, maka akan memunculkan sikap perilaku konsumen yang loyal terhadap suatu merek, dan jika gagal maka merek tersebut akan dilupakan oleh konsumen dan beralih ke merek lain, maka pada penelitian yang dilakukannya bahwa variabel variety seeking berpengaruh positif dan signifikan terhadap brand switching.

Namun hal ini tidak sejalan dengan penelitian yang telah diujikan oleh Ariani (2014) yang menyatakan bahwa mencari keberagaman dapat membuat suasana hati positif dan tampaknya mendorong orang untuk mencari tahu secara lebih, serta menstimulasi mengenai produk-produk yang mereka cari. Terbukti bahwa hal ini dapat meningkatkan berbagai keingin rasatahuan diantara produk-produk yang menyenangkan. Berbeda dengan yang dilakukan oleh Wahyuni \& Kurniawati (2018) bahwa pengaruh variety seeking terhadap brand switching adalah konsumen seringkali mengikuti segala sesuatu yang sedang tren, sehingga selera konsumen pun akan berubah timbulnya rasa kebosanan pada produk yang mereka miliki sehingga dalam hasil penelitianya menunjukan bahwa variety seeking berpengaruh signifikan terhadap brand switching.

\section{$\mathrm{H}_{1}$ : Variety seeking berpengaruh positif dan signifikan terhadap brand switching}




\subsubsection{Pengaruh packaging terhadap brand switching skincare}

Terdapat penelitian yang dilakukan oleh keputusan pembelian produk kosmetik yang dirasakam saat menggunakan merek adalah kelabelan halal pada kemasan, yang mana memudahkan dalam mengambil keputusan pembelian setelah berpindah merek. Hal memungkinkan yang terjadi bahwa kemasan akan mempengaruhi untuk berpindah merek. Hal ini sejalan dengan apa yang dilakukan oleh Lestari, Kurniari, \& Fitrianti (2020) mengatakan bahwa faktor eksternal dalam mempengaruhi pembelian konsumen yaitu dengan adanya stimulus pemasaran salah satunya adalah kemasan akan membuat mereka switching. Purnama, Siswadi, \& Mujiatun (2021) mengatakan hal yang demikian bahwa keterlibatan harga, variasi, dan kemasan mengidentifikasi keragaman sebagai penyebab utama peralihan merek.

Namun hal ini mengalami pertentangan di mana dalam penelitian yang dilakukan oleh Widyasari et al., (2021) yang berasumsi bahwa pada penelitiannya mengatakan dengan objek rokok kemasan, dimana rokok kemasan yang melekat mempunyai merek identitas melalui brand logo, warna, founts, gambar, kemasan bahan dan bentuk. Klaim industri tembakau bahwa ia tidak memiliki kepentingan dalam menarik pelanggan dalam pergantian brand,dibuktikan bahwa kemasan rokok cukup mengerikan, hal ini membuat konsumen melihat produk bukannya menarik untuk melihat dan melakukan perpindahan merek justru akan meninggalkan produk tersebut. Maka kemasan (packaging) tidak membuat peralihan merek pada tiap individu. Pada sisi lain beberapa penelitian justru mengatakan hal sebaliknya yakni adanya merek harga, merek promosi, ketersedian produk, produk kemasan dan kualitas.

\section{$\mathrm{H}_{2}$ : Pacakging berpengaruh positif dan signifikan terhadap brand switching}

\subsection{Kerangka Berfikir :}

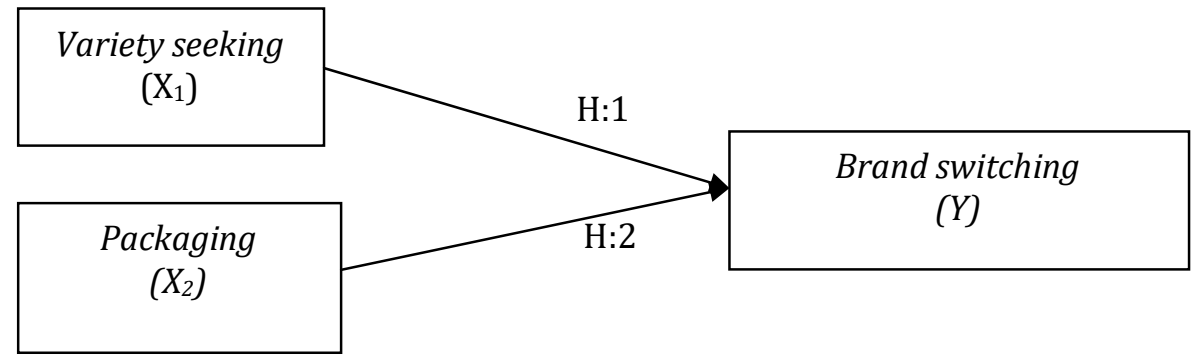

Gambar 1: Kerangka Berfikir

\section{Metode Penelitian}

Penelitian yang dilakukan di negara Indonesia ini merupakan penelitian survey dengan bantuan instrument kuesioner yang dilakukan secara crosssectional atau pada satu waktu tertentu. Penelitian ini dikhususkan pada responden millennial yang lahir kisaran tahun 19822001. Responden adalah orang yang selalu berhubungan dengan internet dan juga pernah melakuan pembelian online serta tahu tentang kartu kredit. Jenis penelitian yang dilakukan oleh penulis merupakan peneliatian yang bersifat kuantitatif. Menurut Sugiyono (2012), penelitian kuantitatif dugunakan untuk meneiliti populasi dan sampel yang dilakukan oleh peneliti dengan pengumpulan data dan menggunakan instrumen penelitian yang dilakukan oleh peneliti itu sendiri, dengan tujuan yang mana adalah dapat menhgui hipotesis yang telah dilakukan diawal dan dugaan sementara. Berdasarkan dugaan yang dilakukan diawal maka terdapat permasalahan dan tujuan yang akan dicapai oleh penulis yaitu menggambarkan keadaan untuk memaparkan penjelasan adanya pengaruh variety seeking, dan packaging terhadap brand switching dengan menggunakan data dalam bentuk angka, yang mana diperoleh melalui penyebaran kuesioner dan menguji kebenaran pada hipotesis yang dibuat diawal sebelumnya. Sumberdatadalampenelitianiniberasaldaridata primer dan sekunder serta menggunakan penyebaran kuesioner. 


\section{Hasil Pembahasan}

\subsection{Hasil Analisis}

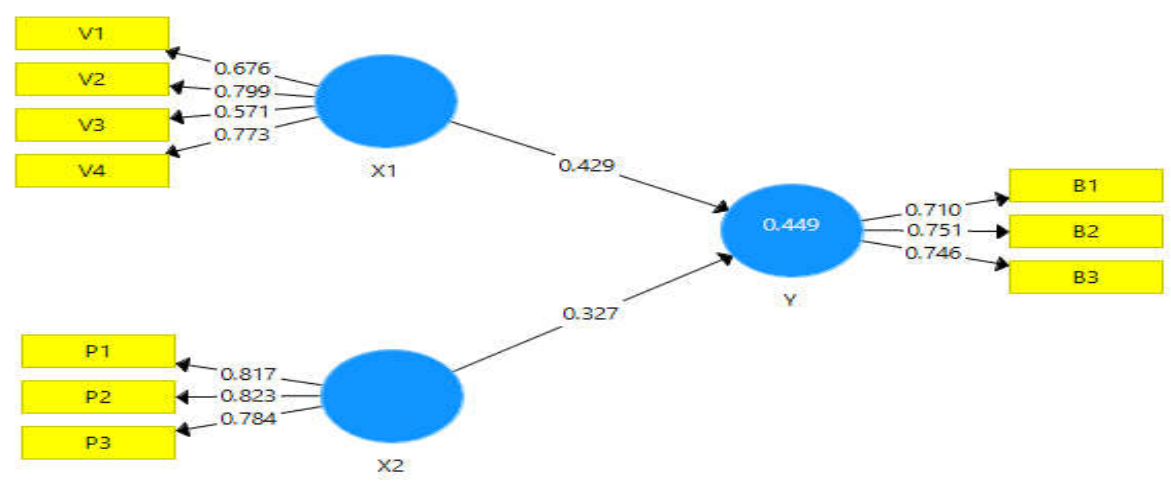

Gambar 2. Uji Validitas

Hasil dari perhitungan yaitu uji validitas pertama memperlihatkan bahwa pada variabel indikator yang gugur, dikarenakan hal ini kurang memenuhi standar 0,6. Yaitu pada indikator X1 yaitu V3=0,571, namun pada indikator X2 dan $\mathrm{Y}$ telah memenuhi syarat yang dimana pada masing-masing indikatornya diatas 0,6. Kemudian dilakukan pengujian ulang yang dimana menghapus indikator yang tidak memenuhi syarat yang dibawah 0,6 dan kemudian hanya dilakukan dengan menguji indikator diatas 0,6.

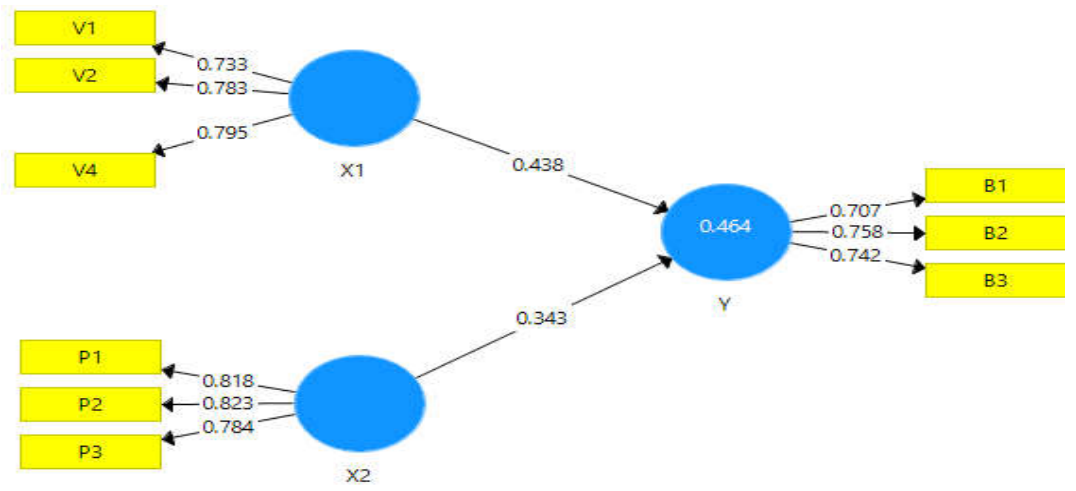

Gambar 3. Uji Reliabilitas

Ketika sudah melakukan uji reliabilitas, namun hal ini masih terdapat indikator dibawah 0,6, maka hal ini indikator yang masih dibawah 0,6 harus segera dihilangkan dan melakukan ulang uji reliabilitas. Adapun uji reliabilitas diatas tidak ada indikator di bawah 0,6.

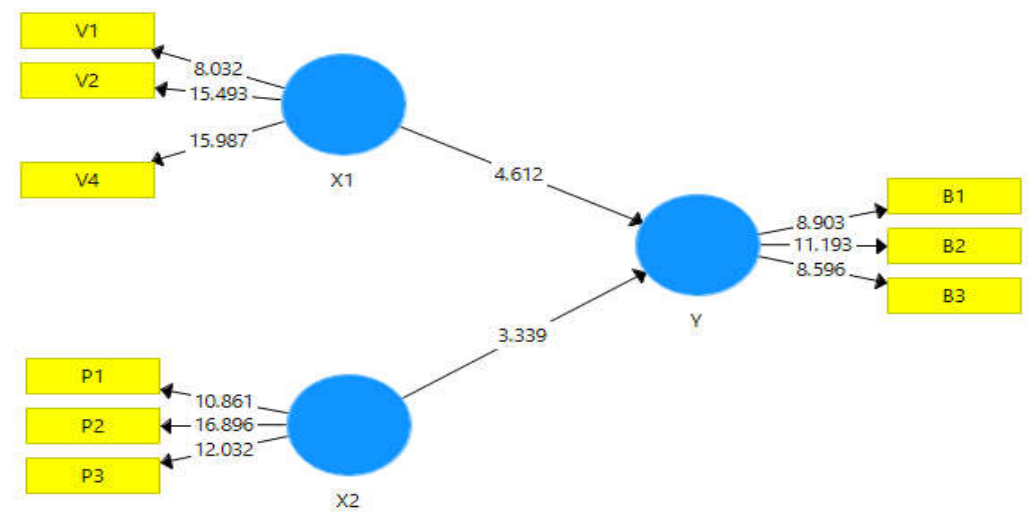

Gambar 4. Uji Validitas dan Reliabilitas 
Maka didapat dari pengujian yang dilakukan pada gambar 4, yang dimana sudah tidak ada lagi indikator yang dibawah 0,6. Yaitu pada indikator X1 terdapat 3 indikator, pada variabel $\mathrm{X} 2$ terdapat 3 indikator dan kemudian pada variabel Y terdapat 3 indikator, maka pada variabel tersebut sudah bisa di uji ke tahap selanjutnya sehingga dapat dilakukan pengujian hipotesis terhadap besarnya pengaruh pada tiap-tiap variabel.

Tabel 1. Data Validitas dan Reliabilitas Konstruksi

\begin{tabular}{|l|l|l|l|l|}
\hline $\mathrm{V}$ & CA & RA & CR & AVE \\
\hline $\mathrm{X}_{1}$ & 0,659 & 0,663 & 0,814 & 0,594 \\
\hline $\mathrm{X}_{2}$ & 0,736 & 0,739 & 0,850 & 0,653 \\
\hline $\mathrm{Y}$ & 0,676 & 0,677 & 0,780 & 0,542 \\
\hline
\end{tabular}

Tabel 2. Data Primer Diolah dengan Smart PLS. 2021

\begin{tabular}{|c|c|c|}
\hline Variabel & T statistic & P Values \\
\hline $\mathrm{X}_{1} \rightarrow \mathrm{Y}$ & 4,612 & 0,000 \\
\hline $\mathrm{X}_{2} \rightarrow \mathrm{Y}$ & 3.339 & 0,001 \\
\hline
\end{tabular}

$$
\begin{aligned}
& \text { Keterangan penjelasan variabel: } \\
& \mathrm{X}_{1} \quad \text { : Variety seeking } \\
& \mathrm{X}_{2} \text { : Packaging } \\
& \mathrm{Y} \quad \text { : Brand Switching }
\end{aligned}
$$

\subsection{Pembahasan}

\subsubsection{Hipotesis 1}

Dari hasil yang telah diuji penulis didapatkan hasil yang di mana variabel variety seeking menunjukan nilai pada P Values sebesar $0,000>0,05$, nilai T-statistic $4.612<1,985$ yang artinnya bahwa pada variabel variety seeking $\left(\mathrm{X}_{1}\right)$ terhadap variabel brand switching (Y) positif dan signifikan. Maka hal ini sesuai dengan beberapa penelitian yang memiliki penelitian Yunita \& Rosa (2016), di dalam penelitiannya menyatakan bahwa hasil pengujian hipotesis variety seeking berpengaruh positif dan signifikan terhadap brand switching di mana terdapat nilai $\mathrm{t}$ hitung $>\mathrm{t}$ tabel $(2,593>1,985)$ maka Ho ditolak dan Ha diterima. Hal ini sejalan dengan penelitian yang dilakukan oleh Indriyani \& Pasharibu (2020), pada penelitiannya terdapat variabel yaitu mencari variasi berpengaruh positif terhadap keputusan perpindahan merek.terbutki bahwa variety seeking berpengaruh secara signifikan terhadap peralihan merek.

\subsubsection{Hipotesis 2}

Dari hasil yang telah diuji penulis didapatkan hasil di mana variabel packaging menunjukan nilai pada $P$ Values sebesar 0,001 yang berarti lebih besar dari pada 0,05 , dan nilai T statistic sebesar 3,339 lebih besar dari 1,985 yang artinnya bahwa pada variabel packaging $\left(\mathrm{X}_{2}\right)$ berpengaruh terhadap variabel brand switching $(\mathrm{Y})$, packaging berpengaruh positif dan signifikan terhadap brand switchingb erdasarkan hasil pengujian yang telah dilakukan didapatkan hasil bahwa sikap packaging berpengaruh positif dan signifikan terhadap brand switchingd engan nilai P. Value $(0.001>0.05)$ dan $\mathrm{T}$ statistic memiliki nilai negatif, sehingga hipotesis 2 tidak didukung. Hasil dari penelitian ini sesuai dengan penelitian yang dilakukan oleh Lestari et al., (2020), yang berasumsi di dalam hasil penelitian kemasan memainkan peranan penting untuk mempengaruhi konsumen untuk beralih dari satu merek ke merek lain, Pada sisi lain beberapa penelitian justru mengatakan hal sebaliknya yakni adanya merek harga, merek promosi, ketersedian produk, produk kemasan dan kualitas. 


\section{Kesimpulan dan Saran}

\subsection{Kesimpulan}

Berdasarkan hasil penelitian dan pembahasan, maka penulis menarik beberapa kesimpulan sebagai berikut :

1) Terdapat pengaruh positif dan signifikan antara variety seeking $\left(X_{1}\right)$ terhadap brand switching $(\mathrm{Y})$ pada konsumen Natasha Skincare di Bandar Lampung. Hal ini dibuktikan dengan nilai original sample (0) 0,438 dari hasil ini didapatkan variety seeking secara positif berpengaruh terhadap brand switching. Nilai T-statistic 4,553> 1,96 dan P-Values $0,000<0,05$. Di mana semakin tinggi tingkat variety seeking maka semakin tinggi pula brand switching pada konsumen.

2) Terdapat pengaruh positif dan signifikan antara packaging $\left(\mathrm{X}_{2}\right)$ terhadap brand switching (Y) pada konsumen Natasha Skincare di Bandar Lampung. Hal ini dibuktikan dengan nilai original sample (0) 0,343 dari hasil ini didapatkan packaging secara positif berpengaruh terhadap brand switching. Nilai T-Statistic 3,197> 1,96 dan P-Values 0,001<0,05. Di mana semakin tinggi tingkat packaging maka brand switching konsumen dalam membeli produk akan tinggi pula.

\subsection{Saran}

Pokok pikiran yang dapat dijadikan saran dari hasil penelitian ini adalah sebagai berikut:

1) Klinik Natasha Skincare sebaiknya menambah jumlah variasi-variasi baru pada produk dan menambah atau menginovasikan packaging yang lebih menarik lagi sehingga dapat membuat pelanggan menjadi loyal dan tidak melakukan brand switching pada produk skincare lain.

2) Bagi peneliti selanjutnya, diharapkan hasil penelitian ini bisa digunakan sebagai bahan perbandingandan referensi untuk penelitian, dan sebagai bahan pertimbangan untuk lebih memperdalam penelitian selanjutnya dengan menggunakan variabel yang berbeda yang tentunya dapatmempengaruhi brand switching, serta menambahkan jumlah sampel sehingga hasil yang didapatkan bervariasi.

\section{Daftar Pustaka}

Ariani, Y. P. (2014). Analisis Faktor-faktor Yang Mempengaruhi Minat Perpindahan Merek Dengan Reference Griup Sebagai Variabel Moderating (Studi kasus pada pengguna provider Indosat M3 di Kota Semarang). Jurnal Sains Pemasaran Indonesia, 13(2), 189210.

Asmoningsih, R. (2015). Pengaruh dari Identity terhadap Brand Value, Satisfcation, Trust dan Brand Loyalty. Jurnal Manajemen Dan Pemasaran Jasa, 8(2), 87-100.

Indriyani, A. R., \& Pasharibu, Y. (2020). Pengaruh Mencari Variasi, Ketidakpuasan Konsumen, Harga dan eWOM Terhadap Perpindahan Merek (Studi Pada Pengguna Smartphone Samsung Galaxy Series yang Berpindah ke iPhone). Jurnal Ekobis Dewantara, 3(2), 1727.

Jannah, M. (2018). Pengaruh Ketidakpuasan Konsumen dan Iklan Pesaing serta Perilaku Mencari Variasi terhadap Perilaku Perpindahan Merek pada Konsumen Shampo Sunsilk di Samarinda. Jurnal Ilmu Manajemen Mulawarnan, 3(4), 1-24.

Kapojos, J. R. (2017). Faktor Perilaku Perpindahan Merek (Brand Switching): Studi Pada Pegawai Pengguna Telepon Seluler Merek Samsung Di Kantor Bupati Minahasa Tondano. Jurnal Riset Bisnis Dan Manajemen, 5(4), 481-502.

Kotler dan Keller. (2017). Manajemen Pemasaran, Edisi 12, Jilid 1, PT.Indeks,. Jakarta. In $e-$ Jurnal Riset Manajemen.

Lestari, M., Kurniari, D., \& Fitrianti, W. (2020). Perpindahan Merek (Brand Swithcing Behavior) pada Air Minum Dalam Kemasan di Kota Pontianak. Jurnal Sains Pemasaran Indonesia, XIX(3), 126-133. 
Lestira, T., Warganegara, P., \& Alviyani, D. (2020). Pengaruh Kualitas Produk Dan Kualitas Pelayanan Terhadap Loyalitas Pelanggan Pada Klinik Kecantikan Puspita Cabang Kotabumi. Jurnal Manajemen Dan Bisnis (JMB), 1(2), 26-33.

Purnama, N. I., Siswadi, Y., \& Mujiatun, S. (2021). Model Perilaku Brand Switching Konsumen Dalam Pembelian Produk Otomotif. Jurnal Ilmiah Manajemen Dan Bisnis, 22(2), 151-163. https://doi.org/10.30596/jimb.v22i2.7305

Septiani, S., \& Purwanti, R. S. (2020). Pengaruh Ketidakpuasan Konsumen Dan Variety Seeking Terhadap Brand Switching (Suatu Studi Pada Konsumen Toko Elin Kosmetik Yang Berpindah Dari Sariayu Ke Wardah). Business Management And Entrepreurship Journal, 2(September), 67-81.

Sugiyono. (2012). Metode Penelitian Kuantitatif, Kualitatif dan R \& D.Bandung:Alfabeta. Metode Penelitian Kuantitatif, Kualitatif Dan $R \quad \& \quad$ D.Bandung:Alfabeta. https://doi.org/10.1017/CB09781107415324.004

Sulistyo, B. A., \& Maftukhah, I. (2016). Analisis Pengaruh Perpindahan Merek Melalui Harga, Iklan, dan Ketidakpuasan Konsumen. Management Analysis Journal, 5(2), 96-103.

Sunyoto, D. (2012). Dasar-Dasar Manajemen Pemasaran (Konsep, Strategi dan Kasus). Yogyakarta: CAPS.

Swastha, B., \& Handoko, T. H. (2012). Manajemen Pemasaran: Analisa Perilaku Konsumen. Yogyakarta: BPFE UGM.

Syauki, W. R., \& Amalia Avina, D. A. (2020). Persepsi dan Preferensi Penggunaan Skincare pada Perempuan Milenial dalam Perspektif Komunikasi Pemasaran. Jurnal Manajemen Komunikasi, 4(2), 42. https://doi.org/10.24198/jmk.v4i2.25719

Tjiptono, \& Fandy. (2015). Strategi Pemasaran (Edisi 4). Yogyakarta: Penertbit Andi.

Wahyuni, D., \& Kurniawati, T. (2018). Pengaruh Price Discount, Bonus Pack, Dan Variety Seeking Terhadap Brand Switching Susu Anlene Ke Merek Lain Di Foodmart Basko Grand Mall Padang. Jurnal Ecogen, 1(2), 416. https://doi.org/10.24036/jmpe.v1i2.4763

Widyasari, S., Gupta, R. K., Khan, D., Banerjee, S., Putra, Y. S., Saras Miranda Putri, Y. dan R. C. S. C. S., ... Indriastuti, H. (2021). Analisis Brand Switching Pada Online Marketplace Shopee Oleh Generasi Z. Trikonomika, 20(1), 299-307. Retrieved from https://umexpert.um.edu.my/file/publication/00005871_112410.pdf\%0Ahttps://journ al.unpas.ac.id/index.php/trikonomika/article/view/3853

Yunita, D., \& Rosa, A. (2016). Pengaruh Mencari Variasi, Ketidakpuasan Dan Ketidak Tersediaan Produk Terhadap Perpindahan Merek. Jurnal Manajemen Dan Bisnis Sriwijaya, 14(4), 539-558. https://doi.org/10.29259/jmbs.v14i4.4518 